\title{
Cross- Model For Creativity Strategic MANAGEMENT
}

\author{
Georgiev, K., Panayotova, T. \& Georgieva, P.
}

Abstract: Creativity is a prerequisite for a successful organizational strategy. The latter can be achieved only if innovation processes are extended beyond the organization management and all individuals in the organization as well as encompass the "crowd". The paper introduces a cross- model of various concepts for Creativity Strategic Mapping. The key point of the Creativity strategy map conception is broadening of participant foundation by involving of the crowd in organizational creative processes.

Key words: innovations; creativity; crowdsourcing; collective intelligence; creativity strategic maps.
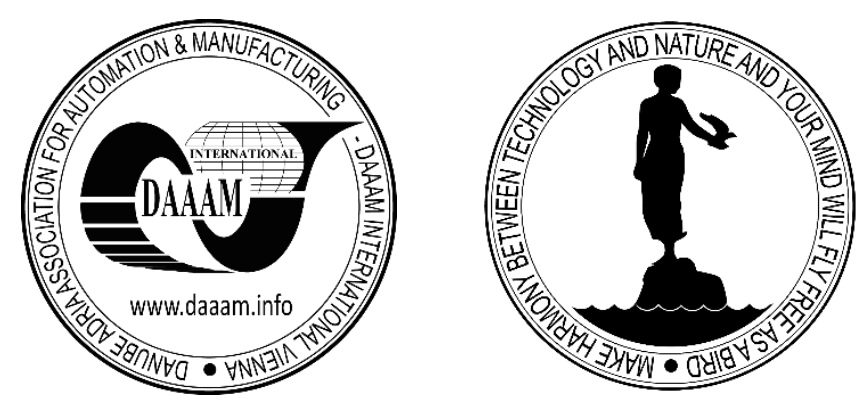

Authors' data: Assoc. Prof. Georgiev, K[iril], Assoc. Prof. Panayotova, T[anya], PhD Georgieva, P[etya], Technical University of Varna, 9000, ul. Studentska 1, Varna, Bulgaria, kirilvg@abv.bg, tagea@abv.bg, petyageorgiewa@abv.bg

This Publication has to be referred as: Georgiev, K[iril]; Panayotova, T[anya] \& Georgieva, P[etya] (2016). Cross- Model for Creativity Strategic Management, Chapter 21 in DAAAM International Scientific Book 2016, pp.225-238, B. Katalinic (Ed.), Published by DAAAM International, ISBN 978-3-902734-09-9, ISSN 17269687, Vienna, Austria

DOI:10.2507/daaam.scibook.2016.21 
Georgiev, K.; Panayotova, T. \& Georgieva, P.: Cross- Model for Creativity Strategi...

\section{Introduction}

During the last decades the focus is shifted from economy based on tangible assets and end products oriented, to economy based on intangible assets, knowledge and service. In this sense creation and implementation of organizational strategy have to ensure respective mobilization and utilization of intangible assets. Throughout the process of strategy implementation the organization has to monitor and measure these significant parameters which will create at long term value. In practice, an effectiveness assessment, managers focus their attention on measurable activities (financial indicators, processes and etc.) and ignore the immeasurable once (entrepreneurial skills, creativeness and etc.). This results in improvement the short term financial indicators only, but opportunities for financing and intangible asset management (human, organizational and information capital) are not taking into consideration. (Kaplan \& Norton, 2006)

Creative organizations survive thanks to their creative results. To achieve such results, organizations need to involve creative staff, creative clients, and management proficiency, as well as to make sure that creative processes are incorporated in organizational strategic planning respectively in its strategic map (Bilton et al, 2003).

To ensure the all aspects are taken into consideration, the strategy map tool is proposed to be used. A strategy map is a diagram developed by the Kaplan and Norton. It is used to document the primary strategic goals being pursued by an organization or management team. It provides the specificity needed to translate general statements about high- level direction and strategy into specific objectives that are more meaningful for all employees and those they can act on.

The authors of the paper introduce the creativity strategy map broader application based on integration of "The Four P's of Creativity" model and crowdsourcing, personas and collective intelligence concepts.

\section{Approaches of researching:}

\subsection{Problem and subject of the research}

Ensuring the success of the company, immeasurable activities could be managed in a long term period, via taking into consideration all aspects of the staff and crowd's creativeness. Based on these findings, the research problem is whether the creative processes could be incorporated and managed in organizational strategic planning and respectively in its strategic map. At the same time it also needs to answer the following questions:

- Could the personas- models, crowdsourcing and collective intelligence concepts be involved in the organizational strategic planning?

- Is the strategy map the appropriate tool for integrating different concepts?

\subsection{The aim of the research}

The aim of the research is to ground the need of the involvement of "The Four P's of Creativity" model, personas models, crowdsourcing and collective intelligence 
concepts into organizational strategic planning and integrate them in Cross- model for creativity strategic management.

\subsection{Hypotheses of the research}

The main hypotheses of the research are:

H1: The organizational strategy for management of creativity has to be based on staff and crowd creativeness.

H2: Creativity management has some significant influence on the company's mission and vision, value for the customer, key processes and persons, culture in the company, resources and best practices.

\subsection{Instruments of the research}

The research, which this paper represents, has empirical and theoretical character. Authors work with relatively open and unstructured research designs. They use the inductive cycle rather than the deductive cycle, utilising some broad spectrum of possible data sources of which the most important ones are observation, informal conversation and in-depth interviews. The collection of data is not structured. The use of theory and concepts is avoided during the early stages of the research. The data is collected and analysed systematically and quantification plays a minor role.

The data is collected from literature sources, the Internet and through interviews with workers and managers of 5 Bulgarian clothing companies and 1 companyproducer of electrical appliances.

\subsection{Limitations of the research}

- The scope of the research covers medium-sized clothing companies and producers of electrical appliances (the number of staff for medium-sized enterprises ranges from 50 to 250 employees).

- The model is applicable to production type of business which involves intensive new-ideas generation.

\section{Theoretical findings}

\subsection{First phase: Companies' problem defining}

The authors conducted some in-depth interviews and informal conversations with the managers and workers in 5 Bulgarian clothing companies and 1 company-producer of electrical appliances. Based on the answers, they extracted the problems in the above-mentioned companies as follows:

- Employee and support of each other is not visible;

- Minimum type of financial rewards, and they are not linked to the value of the ideas/ suggestions;

- Weak feedback to the employees on their ideas/ suggestions;

- There is not a structured schedule to evaluate the suggestions, teams and evaluation criteria;

- There is not a system to elicit the employee's creative ideas; 
Georgiev, K.; Panayotova, T. \& Georgieva, P.: Cross- Model for Creativity Strategi...

- The new revenues are minimal;

- There is a little improvement in employees' sense of accountability and commitment to their organization purpose, employees' job satisfaction, and employees' confidence in an organization;

- No evidence of customer satisfaction or product quality improvement as a result of ideas/ suggestions;

- Employee participation is limited to few employees;

- Organizations has limited talented employees;

- Employees have standard work routines and mostly work under pressure.

It is clear that there are problems in human-resources management, innovation management and strategic management in the companies.

\subsection{Second phase: Theoretical findings}

The authors conducted a research into various literature based on the abovementioned problems for ways to solve those issues arising. The researchers share the opinion that creativity, personas and crowdsourcing are important to the company's success and customer satisfaction. The opinion of Kaplan and Norton is in this direction: Intangible assets such as, creativity, innovation and effective utilization of knowledge are mandatory for survival in business. The managers of the companies have to satisfy the new and captious customers' requirements and mobilize human and information resources in compliance with the organizational strategies. (Kaplan \& Norton, 2006)

In that sense the management of the personas models and creativity, crowdsourcing, and collective intelligence is important to be incorporated into the organizational strategy. Many authors share opinions about the importance of each of the above-mentioned concepts.

During the past decade, personas in product design have received much attention from academicians and innovative companies, an interest that is part of a positive trend toward building user-centric products. Personas provide designers with a user-centric reference tool that depicts an ideal user. This tool allows designers to maintain focus on the ideal user as they explore and develop solutions. (Luchs et al, 2016)

At the stage of problem definition personas define users and set parameters for design solutions, keeping designers from falling into a common design pitfall: designing for oneself. Consciously or not, designers often infer and assume about users based on work experience and industry knowledge. Consequently, personas can be useful to avoid self-referencing, frame design problems from a user's perspective, and focus designers. At the stage of development, personas get an engineering team up to speed quickly. A clearly defined persona makes it easier for designers and engineers to achieve a common understanding about a user and the scope of a solution. It is critical that engineers understand the target persona so they can make the right decisions and trade-offs.

Personas are useful when it comes to communicating with other business functions such as marketing, management, and sales. Personas provide a clear 
definition of a target market and assist a marketing team with aligning a product from inception through promotion. Personas help decision makers understand a problem from a user's perspective and provide a context for evaluating the product concept. (Luchs et al, 2016)

Crowdsourcing refers to a problem-solving and completing tasks model which involves the participation of the Internet crowd. It represents just one of the many ways to harness collective intelligence. Its use has spread increasingly, being used in many areas: medicine, biology, astronomy, etc., being business area the one in which it was born and in which has been more used. (Fernando et al, 2015)

Thanks to the collaborative nature of Web 2.0, crowdsourcing allows a person, institution, or company to benefit from the work, ideas, or wisdom of the crowd of Internet. This crowd, usually heterogeneous, can be formed by amateurs, volunteers, experts, companies, etc., which may or may not belong to a specific user community. The work of this crowd is rewarded in some way: tangible (money, prizes, etc.) or intangible (recognition, entertainment, prestige, etc.). (Fernando et al, 2015)

Collective intelligence is not a new phenomenon and has been in the focus of science and research (biology, social sciences, engineering, computer science, etc.) for many years. Decomposing collective intelligence etymologically, the term "collective" describes a group of individuals who are not required to have the same attitudes or viewpoints. Different members can reveal different perspectives and approaches, and thus leading to better explanations or solutions to a given problem. "Intelligence" refers to the ability to learn, to understand, and to adapt to an environment by using own knowledge. (Leimeister, 2010)

The MIT Centre for Collective Intelligence (Malone, 2009) combines both terms to describe very broadly groups of individuals doing things collectively that seem intelligent. They present a framework for identifying underlying building blocks ("genes") that are at the heart of collective intelligence systems, the conditions under which each gene is useful, and the possibilities for combining and re-combining these genes to harness crowds effectively. Employing an analogy from biology, these building blocks are called the "genes" of collective intelligence systems. A gene is defined as a particular answer to one of the key questions (What, Who, Why or How) associated with a single task in a collective intelligence system. Like the genes from which individual organisms develop, these organizational genes are the core elements from which collective intelligence systems are built. The full combination of genes associated with a specific example of collective intelligence can be viewed as the "genome" of that system. (Malone, 2009)

Ability to innovate is the most important skill for the future. Innovating has to perform, to organize systems capable of continuously creating and developing promising ideas or solutions that can be transformed into powerful, creative new ideas that bring value and wealth. Companies with an innovation culture have institutionalized a reliable, reproducible and flexible work program to generate solutions to problems and create innovative processes/products that will be able to compete with the competition. (Leimeister, 2010) Also, innovating cannot be viewed 
as an independent event. It is part of a larger system process that creates a feedback loop and the necessity of new generative innovations. For organizations to successfully promote and develop innovations there will have to be an alignment between the organization's goals and mission and its attempts to implement innovations. Such linkage has to be accomplished through individuals, and this requirement means a welldeveloped and articulated human resources strategy and plan. While it can be easy to focus on the hardware aspect of innovative advancement, the human side is the true driver of the phenomenon. (Mayfield, 2011)

Managing Creative People is the next important direction. Creative people are unique in their ability to achieve anything, including collective objectives. To maximize creative potential is the concern of each creative individual. It is the particular concern of those responsible for the management of efforts involving creative people. (Kay, 2012)

Networking and creativity: The social context provides an important means of understanding creativity. Understanding social networks is more complicated than understanding the extent a person gathers names or charms others at a social gathering. A social network lens is way of understanding a person's on-going social context. These social contexts vary greatly. As an example, one person may have many friends but may not be very central in the network. Another may not have many friends but may be connected to a highly central person. In contrast, two people may have the same number of contacts, but one person's contacts are also friends whereas the other person's contacts do not interact at all. By considering various social network configurations, we gain knowledge about the extent a person's social context facilitates or constrains creative thinking. Two important ways that networks matter are by providing access to non-redundant knowledge and enhancing creative cognition. Ultimately, creative ideas can be either inspired and nurtured or thwarted and stifled depending on a person's social network context. (Mayfield, 2011)

Organizational culture and creativity: There are three distinct perspectives on the characteristics of an organizational culture:

(1) The integration perspective:

This perspective implies that an organizational culture is a unifying and inclusive force. Central concepts are shared in values and common goals and beliefs. Also a creative environment that provides a basis for innovations should be built. The managerial challenge within this perspective is thus to direct the unitary culture toward creativity and innovation. This may be a great challenge given that many organizations feel forced by competition to focus on efficiency (exploitation) rather than innovation (exploration). Introducing clear-cut creative goals and establishing a communication climate that builds a shared vision are some options managers have in their toolkit.

(2) The differentiation perspective:

The perspective involves a focus on cultural differences and the existence of subcultures. Individuals and groups are expected to have their own needs, perceptions and values, be they organizational or personal. The managerial challenge in the differentiation perspective is to handle the subtle conflicts that arise between different 
cultures. Subcultures may often adopt their own goals which may be at odds with those of the organization (sub-optimization). A possible solution might be to look for how creative knowledge environments of different sizes and at different levels can be created. Letting parties from different subcultures gain common responsibility might help the organization enhance creativity and innovation.

(3) The fragmentation or ambiguity perspective:

The perspective is characterized by the organization being regarded as an arena in which social actors constantly negotiate and renegotiate what they perceive as meaningful in life. In reality, across the perspectives, managers usually face the delicate task of trying to form cultures that build on the best of the various perspectives. Trying to balance the unitary and cohesive culture in the integration perspective with the need for heterogeneity and conflict advocated by the differentiation and fragmentation perspectives may prove difficult. (Mayfield, 2011)

According to above various researches, the suggested Creativity strategy map concept allows an integrated view of management of creativity, crowdsourcing and collective intelligence in organizations.

\section{Creativity strategic map concept}

To elaborate on the topic, current paper integrates "The Four P's of Creativity" model and Strategy map to crowdsourcing and collective intelligence.

In "The Four P's of Creativity" model, five perspectives were distinguished: Press/Place, Person, Processes, Product/ Results.

According to Malone et al. (Malone et al. 2009) research the following elements of collective intelligence building blocks or "genes" are taken into consideration in the map construction: Who is performing the task?- "Who? Gene".

Why are they doing it?- "Why? Gene". What is being accomplished?- "What? Gene". How is it being done?- "How? Gene".

Kaplan and Norton Strategy map involves the four perspectives: Financial, Customer, Internal and Learning \& Growth. 


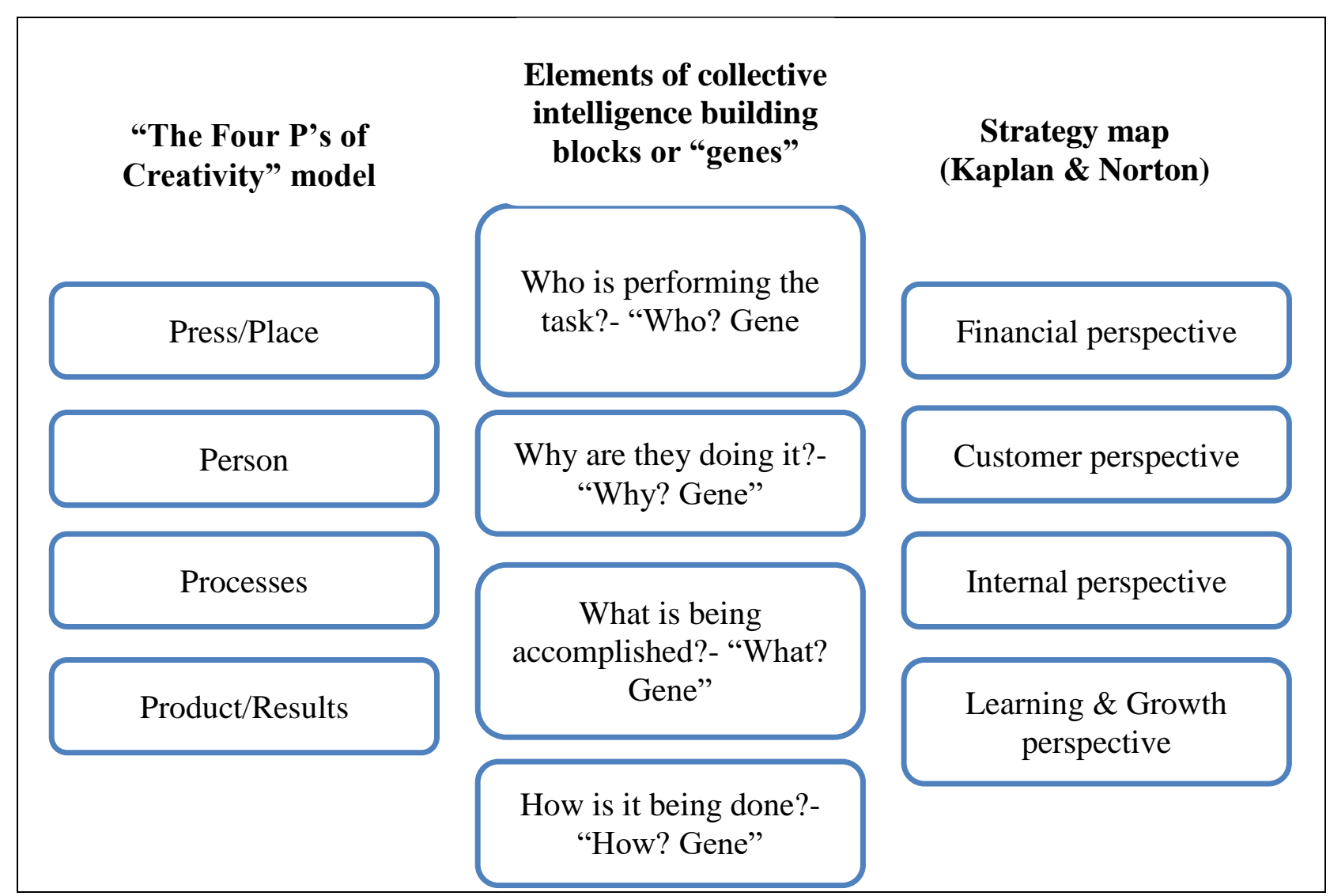

Fig.1. Elements of integration

The current paper introduces the five perspectives which influence creativity as follows:

\section{PRESS/PLACE PERSPECTIVE:}

The perspective characterizes the impact of organizational environment/ place over the creativeness.

For example: (1) organizational culture, which includes positive attitude towards any problems and risk taking, creativity and innovation appraisal, appropriate awards and recognitions, open idea sharing and etc.; (2) organizational resources, which include providing with "creative brains" /individuals generating ideas/; "sponsors" /individuals procuring resources for the idea realization/; "shapers" /individuals implementing the ideas/; "inspirators"/ promoting ideas and persuading individuals to accept them/; "experts" /individuals possessing special knowledge and skills/; and etc. (3) organizational good practices such as appropriate rules and decision liberty, perceiving of difficulties as challenges in the team work, constructive criticism, open communications and etc.

\section{PERSON PERSPECTIVE:}

The perspective defines the key persons /from target crowd groups/ and their profiles, who will participate in decision making, ideas generating of new product/ process development, improvements and modifying and etc. This perspective is to be linked to "Who? Gene". 
For example: (1) For new ideas generating, individuals with unique thinking and skills are needed; (2) With regard to personality, individuals must be open to uncertainty; (3) With regard to motivation, individuals must be externally and selfmotivated, as well as goal oriented; (4) With regard to trust, individuals must be open to it and share within the team.

\section{PROCESS PERSPECTIVE:}

The perspective defines the key processes, to be linked to "How? Gene". Processes examples: Processes carried out by the organizational team: (1) Preparationproblem identifying and acquiring a preliminary knowledge, data/ information. (2) Incubation- defining the problem and desired result. (3) Insight- ideas generating for problem solution; (5) Evaluation- assessment of problem solutions. (6) Elaborationselection of the most appropriate problem solution and its practical realization.

Processes carried out by the crowd could be structured by the following ways (Table 1):

\begin{tabular}{|l|l|l|}
\hline $\begin{array}{l}\text { Create- the actors in the } \\
\text { system generate } \\
\text { something new }\end{array}$ & $\begin{array}{l}\text { Independent } \\
\text { Collection- the items } \\
\text { contributed by members } \\
\text { of the crowd are created } \\
\text { independently of each } \\
\text { other }\end{array}$ & $\begin{array}{l}\text { Dependent } \\
\text { Collaboration- members } \\
\text { of a Crowd work together } \\
\text { to create something and } \\
\text { important dependencies } \\
\text { exist between their } \\
\text { contributions }\end{array}$ \\
\hline $\begin{array}{l}\text { Decide- the actors } \\
\text { evaluate and select } \\
\text { alternatives. A key } \\
\text { determinant of the answer } \\
\text { to this question is whether } \\
\text { the different members of } \\
\text { the crowd make their } \\
\text { contributions and } \\
\text { decisions independently } \\
\text { of each other or whether } \\
\text { there are strong } \\
\text { dependencies between } \\
\text { their contributions }\end{array}$ & $\begin{array}{l}\text { Individual Decisions- } \\
\text { occurs when members of } \\
\text { a Crowd make decisions } \\
\text { crowd input, do not need } \\
\text { to be identical for all. }\end{array}$ & $\begin{array}{l}\text { Group Decision- occurs } \\
\text { when inputs from } \\
\text { members of the crowd are } \\
\text { assembled to generate a } \\
\text { decision that holds for the } \\
\text { group as a whole. }\end{array}$ \\
\hline
\end{tabular}

Tab. 1. Variations of the "How? Gene" for Crowds (Malone et al, 2009)

Important variants of the Group Evaluation gene are Voting, Consensus, Averaging, and Prediction Markets.

- Voting: An important sub-variation of voting is implicit voting, where actions like buying or viewing items are counted as implicit "votes". Another important subvariation involves weighted voting. For example, Google ranks search results, in 
Georgiev, K.; Panayotova, T. \& Georgieva, P.: Cross- Model for Creativity Strategi...

part, on the basis of how many other sites link to the sites in the list. But Google's algorithm gives more weight to links from sites that are, themselves, more popular.

- Consensus: Consensus means that all, or essentially all, group members agree on the final decision.

- Averaging: In cases where decisions involve picking a number, another common practices is to average the numbers contributed by the members of the Crowd. Averaging is commonly used in systems that rely on a point scale for quality rating.

- Prediction markets: Useful way of letting crowds estimate the probability of future events is with prediction markets. In prediction markets, people buy and sell "shares" of predictions about future events. If their predictions are correct, they are rewarded, either with real money or with points that can be redeemed for cash or prizes.

Individual Decisions: The Individual Decision gene occurs when members of a crowd make decisions that, though informed by crowd input, do not need to be identical for all.

- Markets: In Markets, there is some kind of formal exchange (like money) involved in the decisions. Each member of the crowd makes an individual decision about what products to buy or sell.

- Social Networks: In Social Networks, members of a crowd form a network of relationships that, depending on the context, might translate into levels of trust, similarity of taste and viewpoints, or other common characteristics that might cause individuals to feel an affinity for one another. Crowd members assign different weights to individual inputs on the basis of their relationship with the people who provided them and then make individual decisions.

CUSTOMER PERSPECTIVE- customer expectations are identified. These expectations are transformed into problem and solutions. The customer expectations generate the product/ service/ process alternations as well as the cause for the organizational creative approach. It is to be linked to "Why? Gene".

Customer value determent: According to (Kai, 2007) Sherden and Gale provided a broader definition for customer value. In their definition, customer value is perceived benefit (benefits) minus perceived cost (liabilities).

Value $=$ Benefits - Liabilities

The benefits include the following categories:

- Functional benefits

- Product functions, functional performance levels

- Economic benefits, revenues (for investment services)

- Reliability and durability

- Psychological benefits

- Prestige and emotional factors, such as brand name reputation. 
- Perceived dependability (for example, people prefer a known brand rather than an unknown brand).

- Social and ethical reasons (for example, environmentally friendly brands)

- Psychological awe (many first-in-market products not only provide unique functions, but also give customers a tremendous thrill; for example, the first copy machine really impressed customers)

- Psychological effects of competition. For example, if there are many competitors producing a same or similar product that usually will create a perception that this product is a commodity and it doesn't carry much value?

- Service and convenience benefits

- Availability (how easy is it to access the product or service?)

- Service (how easy is it to get service in case of product problems or failure?)

- The liabilities include the following:

- Economic liabilities

- Price

- Acquisition cost (such as transportation and shipping costs, time and effort spent to obtain the service)

- Usage cost (additional cost to use the product or service in addition to the purchasing price, such as installation)

- Maintenance costs

- Ownership costs

- Disposal costs

- Psychological liabilities

- Uncertainty about the dependability of the product or service

- Self-esteem liability of using an unknown brand product

- Psychological liability of poor performance of the product or service

- Service and convenience liability

- Liability due to lack of service

- Liability due to poor service

- Liability due to poor availability (such as delivery time, distance to shop)

\section{RESULT PERSPECTIVE:}

The perspective reflects the expected results by the management. It is to be linked to "What? Gene".

For example: in traditional organizations, the answer to this question is often spoken of as the mission or goal. It could be Product/process functionality enhancements/ improvements and/or new products/ processes. 
Georgiev, K.; Panayotova, T. \& Georgieva, P.: Cross- Model for Creativity Strategi...

Mission and Vision of a Creative company: What?

Results Perspective /management expectations/

Product/process functionality enhancements/ improvements

New products/

processes

Customer Perspective /value for the customer/: Why?

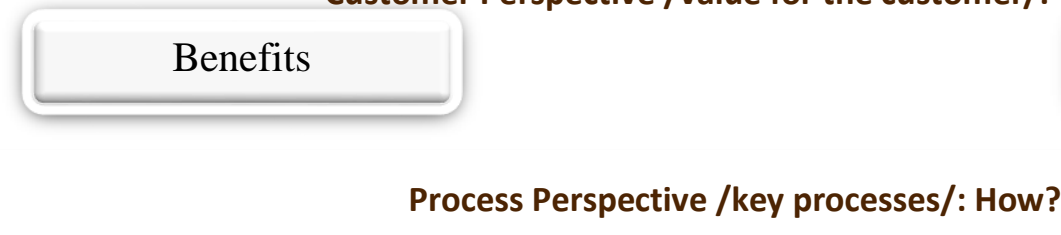

Liabilities

CREATED by crowd

DECIDED by crowd

Processes carried out by the organizational team

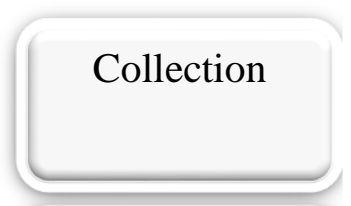

Collaboration
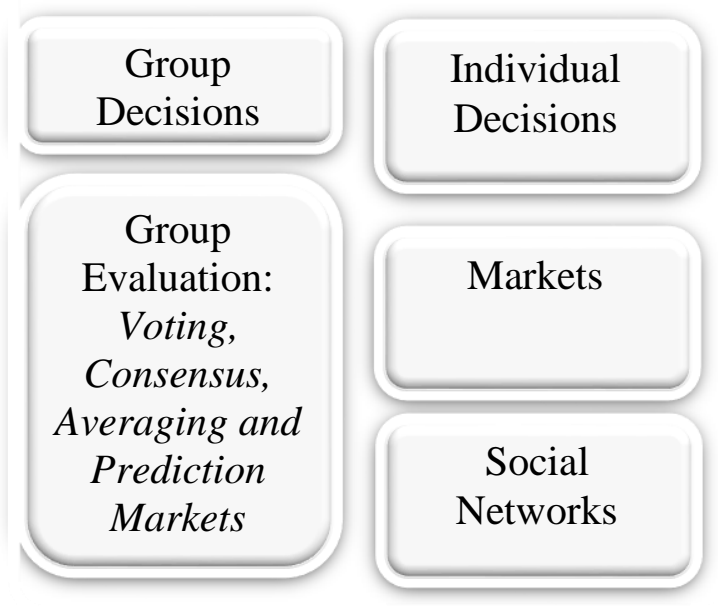

Preparation Incubation

Insight

Evaluation

Elaboration

Person Perspective /persons in key processes/: Who?

Crowd: target crowd groups, personas profiles and etc.
Organizational team

Organizational (best) practices:

Autonomy, Mastery, Relatedness and Purpose

Fig. 2. Creativity Strategy Map 


\section{Conclusion}

The contribution of the research is introducing the cross model of various concepts: Strategy map, “The Four P's of Creativity", Crowdsourcing, Personas and Collective intelligence, thus ensuring profound analyses in multiple perspectives. The key point of the Creativity strategy map conception is broadening of participant foundation by involving of the crowd in organizational creative processes.

After practical application of the map in 2 of the companies and conducting the interviews with the 2 managers and 6 workers the authors found that:

- Management of creativity has significant influence on the company's mission and vision, value for the customer, key processes and persons, culture in the company, resources and best practices.

- The organizational strategy for creativity management is based on the staff and crowd creativeness.

- The model is applicable for enterprises which are capable of ensuring the necessary financial resources and human staff.

- The application of the model needs additional settings to each and every specific company's environment.

- The usage of this model is appropriate for firms whose business is based on production with intensive new- ideas generation.

The potential benefits are:

- building a pool of ideas and turning voice of the customer into new product development;

- new product development cost reduction and speed up;

- large scale of ways for customer opinions involvement;

- early recognition of customer dissatisfaction;

- increasing of customer loyalty taking into consideration of their opinions and advices;

- customer involvement in extending the product promotional time line due to their awareness to product forming;

- potential to change customer behavior and resumption of interest in old products;

- building of strong public relations.

The area of authors' further research will be:

- Adjustment of the tool to the different types of business;

- Development of a software application model.

\section{References}

Bilton, C.; Cummings, S. \& Wilson, D. (2003). Strategy as Creativity, In Cumming S. \& Wilson, D., Images of Strategy, Wiley-Blackwell, ISBN: 978-0-631-22609-3 Chaouki, J. (2014). Innovate: Yes You Can, Volume 83, Pages 16-18, Proceedings of the "SYMPHOS 2013", 2nd International Symposium on Innovation and Technology in the Phosphate Industry, Elsevier Ltd., Available from: 
Georgiev, K.; Panayotova, T. \& Georgieva, P.: Cross- Model for Creativity Strategi... http://www.sciencedirect.com/science/article/pii/S1877705814010972, Accessed: 2016-07-09

Fernando J.; Gil-Pechuán, I. \& Estelles-Miguel S., (2015). Chapter 3, Crowdsourcing Fundamentals: Definition and Typology, Advances in Crowdsourcing, Springer International Publishing Switzerland, ISBN 978-3-319-18341-1

Kai, Y., (2007). Voice of the Customer: Capture and Analysis, The McGraw-Hill Company, ISBN:0071465448, e-ISBN: 0071593411, pp.107.

Kaplan, R. \& Norton, D., (2006). Strategy Maps: Converting Intangible Assets into Tangible Outcomes, Klasika \& Stil, ISBN-10: 954-327-024-4, ISBN-13: 978-954-327024-6, Sofia, Bulgaria

Kay, R., (2012). Managing Creativity in Science and Hi-Tech, pp.9, ISBN 978-3-64224634-0 e-ISBN 978-3-642-24635-7, Springer-Verlag Berlin Heidelberg 2012

Leimeister, J. (2010). Collective Intelligence, Business \& Information Systems Engineering, Volume 2, Issue 4, 2010, pp. 245-248, ISSN: 2363-7005 (Print) 18670202(Online), Available from: http://link.springer.com/journal/12599/2/4/page/1, Accessed: 2016-07-09

Luchs, M.; Swan, K. \& Griffin, A. (2016). Design thinking: new product development essentials from the PDMA, pp.45-60, John Wiley \& Sons, Inc., ISBN: 978-1-11897180-2, Hoboken, New Jersey

Malone, T.; Laubacher, R. \& Dellarocas, C. (2009) Harnessing crowds: mapping the genome of collective intelligence, Working Paper No. 2009-001, Available from: http://cci.mit.edu/publications/CCIwp2009-01.pdf, Accessed: 2016-07-09

Mayfield, M., (2011). Innovation, pp.658, In Runco, M.; Pritzker, S., Encyclopedia of creativity, Second edition, Elsevier Inc., ISBN: 978-0-12-375039-6 